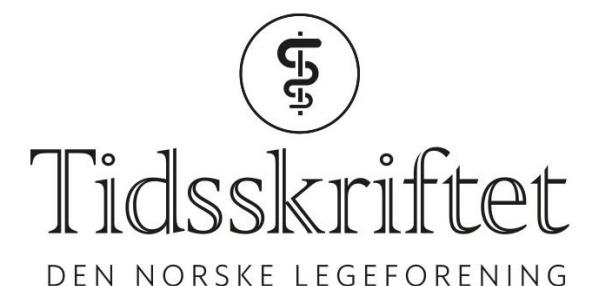

DEN NORSKE LEGEFORENING

\title{
G. Hasle svarer
}

KOMMENTAR

\section{GUNNAR HASLE}

E-post: hasle@reiseklinikken.com

Gunnar Hasle er lege ved Reiseklinikken.

Forfatteren har ikke oppgitt noen interessekonflikter.

Insidensen av maligne melanomer er over tre ganger så høy i Norge som i Spania (1). Dette understreker det mange vitenskapelige studier viser, nemlig at hudtype er en svært viktig faktor for melanomrisikoen. Den norske solvaneundersøkelsen viser at det i hovedsak er hjemme i Norge vi blir solbrent (2). Derfor er reiser til Spania ikke noen god forklaring på $ø$ kningen i melanomer. En eventuell overdiagnostisering kan ikke forklare femdoblingen i dødelighet. Mitt poeng er at vi ikke vet årsakene til denne økningen. Gjersvik, Landrø og Roscher begynner innlegget med å slå fast at malignt melanom kan forebygges. Det er kanskje riktig, men vi vet ikke nok om hvordan det kan forebygges.

Gjersvik, Landrø og Rocsher skriver at D-vitamin i praksis ikke påvirkes av solkrem. Hvordan vet de det? Jeg viser til en metaanalyse i artikkelen, hvor de to eksperimentelle studiene viser en signifikant reduksjon av D-vitamin hos dem som fikk solbeskyttende krem i forhold til dem som ikke fikk det. Skal man undersøke effekten av solkrem må det gjøres eksperimentelt, ikke i form av feltstudier hvor det er umulig å ha kontroll på hvor mye UVB man utsettes for og hvor mye solkrem man bruker. Matsouka et al. sier det så sterkt det går an: «Whole body application of sunscreen completely blocks the vitamin $\mathrm{D}_{3}$ response to $\mathrm{UVB} »(3)$.

Jeg ser at Gjersvik, Landrø og Roscher langt på vei er enige i at vi ikke har holdepunkter for at solkrem kan redusere risikoen for maligne melanomer. Kan vi ikke da være enige om å slutte å anbefale solkremer, unntatt i de tilfellene det er umulig å unngå solbrenthet på andre måter? Vi snakker her om et marked av størrelsesorden 130 milliarder kroner i året (4) for produkter vi ikke har holdepunkter for at er godt for noe som helst.

\section{LITTERATUR:}

1. Forsea AM, Del Marmol V, de Vries E et al. Melanoma incidence and mortality in Europe: new estimates, persistent disparities. Br J Dermatol 2012; 167: 1124-30. [PubMed][CrossRef]

2. Kantar TNS. Solvaner i den norske befolkningen. Oslo: Kreftforeningen, 2018. https://kreftforeningen.no/wp-content/uploads/2018/o9/solvaneundersokelse_rapport-juni2018.pdf. Lest 3.9.2019.

3. Matsuoka LY, Wortsman J, Hollis BW. Use of topical sunscreen for the evaluation of regional synthesis of vitamin D3. J Am Acad Dermatol 1990; 22: 772-5. [PubMed][CrossRef] 
4. Fact.MR. Sun Protection Products Market Forecast, Trend Analysis \& Competition Tracking: Global Market Insights 2019 to 2029. https://www.factmr.com/report/140/sun-protection-products-market. Lest 8.12.2019.

Publisert: 13. januar 2020. Tidsskr Nor Legeforen. DOI: 10.4045/tidsskr.19.0796

(C) Tidsskrift for Den norske legeforening 2020. Lastet ned fra tidsskriftet.no 